\title{
Bentuk Tari Renteng di Dusun Saren I, Nusa Penida, Klungkung
}

\author{
Anak Agung Gde Agung Indrawan ${ }^{1}$ I Ketut Sariada ${ }^{2}$, Ni Made Arshiniwati ${ }^{3}$ \\ ${ }^{1}$ Pengkajian Seni Tari Program Magister Program Pascasarjana, \\ Institut seni Indonesia Denpasar \\ ${ }^{2}$ Program Magister Program Pascasarjana, Institut Seni Indonesia Denpasar \\ ${ }^{3}$ Program Magister Program Pascasarjana, Institut Seni Indonesia Denpasar \\ 'agungindrawan88@gmail.com
}

Tari Renteng yang terdapat di Dusun Saren I, Nusa Penida, Klungkung adalah tarian sakral yang dibawakan oleh sekelompok orang dengan gerak, busana, dan iringan musik yang sangat sederhana. Tarian ini memiliki keunikan tersendiri yaitu bentuknya yang sederhana dan ditarikan secara berulang-ulang, terdapat prosesi ritual yang harus dilakukan oleh penari sebelum dipentaskan, memiliki keterkaitan dengan Pura Penataran Ped. Tujuan penelitian ini adalah untuk mendeskripsikan tari Renteng secara umum, dan khususnya memahami tarian ini melalui bentuknya. Metode yang digunakan dalam penelitian ini adalah kualitatif, dengan teknik pengumpulan data berupa observasi, wawancara, dan dokumentasi. Teori yang diterapkan adalah teori bentuk bermakna. Hasil penelitian menunjukkan bahwa bentuk tari Renteng di Dusun Saren I, Nusa Penida, Klungkung dapat dilihat dari gerak tari, struktur pertunjukan, dan elemen-elemen pertunjukannya. Kesimpulannya adalah bentuk tari Renteng di Dusun Saren I, Nusa Penida, Klungkung adalah tarian sakral yang ditarikan secara massal oleh sekelopok wanita dewasa berjumlah ganjil. Terdiri dari tiga gerak pokok yaitu ngelikas, nguler, dan mentang. Struktur pertunjukannya meliputi bagian awal, tengah, dan akhir. Tempat pentas yang digunakan yaitu pentas arena. Penarinya adalah wanita yang sudah menikah, berasal dari Dusun Saren I, dan menjadi penari atas keinginannya sendiri. Terdapat sesajen yang digunakan untuk mendak renteng. Rias yang digunakan adalah rias natural, sedangkan busananya yakni pakaian adat persembahyangan yang menjadi busana tari, dan diiringi dengan gamelan rerentengan.

Kata Kunci: bentuk, tari Renteng, Saren

\section{Form Of Renteng Dance In Saren I Hamlet, Nusa Penida, Klungkung}

Renteng dance, which is located in Saren I Hamlet, Nusa Penida, Klungkung, is a sacred dance performed by a group of people with very simple movements, clothes, and musical accompaniment. This dance has its uniqueness, namely its simple form and is danced repeatedly, there is a ritual procession that must be performed by the dancer before it is performed, it has a connection with the Penataran Ped Temple. The purpose of this research is to describe Renteng dance in general, and in particular to understand this dance through its form. The method used in this research is qualitative, with data collection techniques in the form of observation, interviews, and documentation. The theory applied is a theory of meaningful forms. The results showed that the form of the Renteng dance in Saren I hamlet, Nusa Penida, Klungkung can be seen from the dance movements, performance structures, and performance elements. The conclusion is that the Renteng dance form in Saren I Hamlet, Nusa Penida, Klungkung is a sacred dance that is danced en masse by an odd number of adult women. Consists of three main movements, namely ngelikas, nguler, and mentang. The performance structure includes a beginning, middle, and end. The stage used is the arena stage. The dancer is a married woman, comes from Saren I hamlet, and becomes a dancer of her own accord. Some offerings are used to join together. The make-up used is natural, while the clothes are traditional prayer clothes that become dance clothes, and are accompanied by rerentengan gamelan.

Keywords: form, Renteng dance, Saren

Proses Review : 2 - 28 Januari 2021, Dinyatakan Lolos: 16 Februari 2021 


\section{PENDAHULUAN}

Bentuk merupakan suatu perwujudan konkret dari objek secara visual yang tersusun dari kesatuan berbagai unsur atau elemen. Dalam seni tari, bentuk tari adalah penyatuan unsur-unsur tari sehingga memiliki wujud, yang keseluruhan dapat memberikan atau menimbulkan rasa estetis bagi yang melihatnya. Menurut Plotinus, "bentuk adalah keterpaduan antar bagian secara serasi dalam sebuah kesatuan" (Suryajaya, 2016). Langer mengartikan bentuk tersebut secara abstrak sebagai katagorisasi dari susunan yang saling terkait atau berhubungan. Selanjutnya, untuk dapat melihat atau memahami susunan tersebut, perlu adanya penelusuran elemen-elemen pembentuknya secara mendalam melalui sebuah analisis (Langer, 2006). Hal tersebut diungkapkan sebagai berikut.

Pendapat lain memberikan penjelasan bentuk dalam tari adalah integrasi perwujudan keseluruhan melalui susunan unsur atau elemen tari. "Bentuk adalah organisasi dan kekuatan-kekuatan sebagai hasil struktur internal atau bagian tari" (Soedarsono, 1999). Sedangankan Jacqueline Smith (1985) menyatakan bahwa "bentuk adalah wujud keseluruhan dari sistem, dan dari keseluruhan tari tersebut membentuk suatu rangkaian yang menyatu" (Suryawati, 2018). "Bentuk tari sebagai perpaduan antara bentuk luar dan imajinasi penari. Tarian itu sendiri merupakan bentuk sajian yang terdiri dari beberapa komponen dalam suatu proses keseluruhan medium" (Tasman, 2008). Berdasarkan pendapat-pendapat tersebut, dengan demikian bentuk tari dapat diartikan sebagai keterpaduan antar unsurunsur tari yang terintegrasi dalam satu kesatuan sehingga memberikan wujud secara keseluruhan.

Tari secara umum dapat didefinisikan sebagai ungkapan ekspresi jiwa manusia melalui gerak-gerak ritmis dan indah. Tari diartikan secara sederhana sebagai "gerakgerak tubuh manusia yang ritmis dan indah" (Sumaryono, 2017). Dengan demikian, dapat dikatakan bahwa tari adalah susunan gerak-gerak ritmis dari anggota tubuh yang dipolakan dalam ruang dan waktu, serta dipengaruhi oleh ekspresi dan emosi untuk menyatakan tata laku dan tata rasa sehingga menimbulkan keindahan bagi penghayatnya. Tari sebagai sarana ritual sering dijumpai di berbagai daerah bahkan di Bali sendiri. Pada umumnya, tari ritual dimiliki oleh sekelompok masyarakat dan bersifat sakral. Bentuk tari ritual sangat sederhana, ditarikan secara berkelompok atau massal dengan gerakan yang sederhana bahkan busana dan iringan musiknya pun sangat sederhana. "Tari ritual dapat dikatagorikan sebagai tarian primitif, jenis tarian dengan bentuk gerak sederhana yang sering dihubungkan dengan kekuatan alam, supranatural, maupun pemujaan atau komunikasi dengan dewa-dewa, serta ritual penyembahan kepada roh nenek moyang" (Hadi, 2007: 14). Van Peursen mengatakan, "bentuk ritual mencerminkan ekspresi estetis dan kepercayaan masyarakat akan kehadiran kekuatan Adikodrati, bertujuan untuk mempengaruhi roh agar tujuan dan kepentingan pelaku ritus terpenuhi" (Suharti, 2013).

Istilah ritual digunakan untuk menyebutkan bentuk dari sebuah peristiwa atau serimonial dalam kegiatan keagamaan maupun berhubungan dengan kepercayaan dari sekelompok masyarakat. Thomas F. O'Dea (1995) memberikan definisi ritual sebagai "suatu bentuk upacara atau perayaan (celebration) yang berhubungan dengan beberapa kepercayaan atau agama dengan ditandai sifat khusus, yang menimbulkan rasa hormat yang luhur dalam arti merupakan suatu pengalaman yang suci” (Hadi, 2006). Kata ritual sebagai "sebuah bentuk penekanan pada fungsi kesakralan" (Heriyawati, 2016). Berdasarkan kedua pendapat tersebut, ritual dapat dikatakan sebagai sebuah peristiwa atau perayaan dari berbagai kepercayaan yang lebih menekankan fungsi kesakralannya. Jika dikaitkan antara tari dan ritual, keduanya merupakan objek yang mengungkapkan ekspresi jiwa manusia dalam bentuk tata laku yang berhubungan dengan suatu kepercayaan yang diyakininya. Dengan kata lain, tari dan ritual adalah simbiosimutualisme, artinya antara tari dan ritual saling melengkapi dan membutuhkan. Terdapat berbagai macam atau jenis tari ritual seperti tari Renteng Sanghyang, Barong Brutuk, Igel Desa, dan lain sebagainya yang ada di Bali. Atau tari Seblang, tari Topeng Cirebon yang ada di luar Bali. Jenis tari-tarian tersebut berhubungan dengan upacara keagamaan, sebagai legalitas sosial masyarakat, berkaitan dengan alam, dan lain sebagainya. Salah satunya adalah tari ritual yang terdapat di Dusun Saren I, Desa Pekraman Mujening Tembeling, Desa Dinas Batumadeg, Nusa Penida, Klungkung.

Dusun Saren I merupakan salah satu dari tiga desa adat yang menjadi satu desa pekraman. Namun, secara administratif kedinasan yang terdaftar hanyalah dua desa adat, yaitu Dusun Saren I dan Dusun Saren II. Dusun Saren I merupakan desa adat yang berdiri sendiri, sedangkan Dusun Saren II merupakan gabungan dari dua desa adat yakni Desa Adat Dahan dan Desa Adat Pangkung Anyar. Dusun Saren I adalah salah satu desa adat yang menjadi bagian dari Desa Dinas Batumadeg secara administratif, yang berbatasan dengan Dusun Batumadeg Kaja di sebelah utara, Dusun Saren II di sebelah timur, Dusun Pangkung Gede dan Samudera Indonesia di sebelah selatan, serta Dusun Batumadeg Kelod di sebelah barat. Jarak antara Dusun Saren I ke Kecamatan Nusa Penida adalah 10 $\mathrm{km}$, dengan waktu tempuh kurang lebih 30 menit sampai dengan 40 menit dengan kendaraan bermotor melewati perbukitan. Dusun Saren I memiliki beberapa kesenian, baik yang dimiliki secara turun-temurun maupun bersifat popular. Kesenian yang dimiliki secara turun-temurun adalah kesenian tari yang dikhususkan dalam upacara keagamaan, yaitu tari Renteng yang dipentaskan pada upacara dewa yadnya dan tari Baris Tombak yang khusus dipentaskan pada upacara pitra yadnya. Sedangkan yang bersifat populer adalah tari Rejang Dewa, tari Rejang 
Renteng, dan tari Rejang Sari. Keseluruhan tarian tersebut memang dipentaskan dalam upacara keagamaan, akan tetapi dua tarian yaitu tari Renteng dan tari Baris Tombak merupakan tarian khusus yang masuk dalam rentetan upacara. Sedangkan tiga tarian lainnya bersifat tidak tetap, artinya dalam kegiatan upacara keagamaan tiga tarian tersebut (tari Rejang Renteng, tari Rejang Dewa, dan tari Rejang Sari) boleh ada ataupun tidak. Karena ketiga tarian tersebut sifatnya hanya mengisi ruang kosong kegiatan upacara keagamaan sebelum salah satu tarian utama yang menjadi rentetan upacara dipentaskan. Selain seni tari, Dusun Saren I juga memiliki seperangkat gamelan Gong Kebyar dan gamelan Balaganjur, serta satu kelompok sekeha pesantian yang terdiri dari lima orang. Selebihnya, tidak ada potensi seni lainnya yang menonjol.

Tari Renteng merupakan salah satu objek kesenian yang menjadi penelitian di Dusun Saren I, Nusa Penida, Klungkung. Tarian ini memiliki keunikan tersendiri, yaitu bentuk yang sederhana dan ditarikan secara berulangulang; terdapat prosesi yang harus dilakukan oleh penari sebelum dipentaskan; memiliki keterkaitan dengan Pura Penataran Dalem Ped; dan harus ditarikan dengan jumlah ganjil. Selain itu, tarian ini juga memiliki mitos yang sampai saat ini dipercaya oleh masyarakat setempat. Kata Renteng berdasarkan etimologinya dapat diartikan sebagai "dalam untaian atau dalam deretan" (Maharsi, 2009). Yudabakti dan Watra juga mengartikan "Renteng sebagai suatu untaian" (Yudabakti, I Made; Watra, 2007). Namun, pendapat lain mengatakan istilah "Renteng diartikan tua. Akan tetapi, tidak diartikan sebagi tua tubuh melainkan seseorang yang dituakan oleh masyarakat setempat" (Diastini, 2018). Jero Mangku Gede Ngurah selaku pemangku di Merajan Kawitan Keniten, mengartikan istilah Renteng tersebut berbeda dengan yang disampaikan oleh Ida Ayu Diastini. "Renteng dapat dikatakan sebagai rentetan, pengertiannya adalah tarian ini menjadi satu kesatuan atau bagian upacara piodalan yang dilaksanakan" (wawancara, 5 Februari 2020). Istilah Renteng yang disampaikan oleh Jero Mangku Gede Ngurah, dan yang terdapat dalam Kamus Jawa Kawi Indonesia memiliki pengertian yang sama. Penulis menginterpretasikan bahwa istilah Renteng tersebut merupakan istilah yang diberikan oleh masyarakat setempat terdahulu pada tarian ini, karena menjadi bagian yang tidak dapat dipisahkan dari pelaksanaan upacara keagamaan. Ida Bagus Mahardika menjelaskan arti kata renteng sebagai berikut.

"Merujuk pada kamus bahasa jawa kuno Indonesia, kata renteng tidak bisa diartikan menjadi rente maupun renta. Arti renteng sebenarnya adalah "dalam untaian atau dalam deretan" (Zoetmulder, 2004). Jika dicari dalam kamus Bahasa Bali, renteng diartikan gencet atau gancet; sarenteng artinya a gencet atau a gancet; berentengrenteng diartikan magencet-gencet atau marence-rence. Tidak ada disebutkan renteng tersebut adalah rente atau renta" (wawancara, 10 Agustus 2020).
Tari Renteng di Dusun Saren I, Nusa Penida, Klungkung merupakan salah satu tarian sakral yang difungsikan sebagai tari ritual keagamaan. Ditarikan secara berkelompok dengan gerak, busana, dan musik iringan yang sederhana. Sebagai seorang penari tradisi yang sangat mengagumi dan menghormati kesenian-kesenian klasik, penulis merasa tergerak untuk mengkaji atau melakukan penelitian pada tarian ini karena terjadi distorsi dan marginalisasi bentuk yang diakibatkan oleh viralnya salah satu tari kreasi baru yang bernuasa ritual, yaitu tari Rejang Renteng Dinas Kebudayaan Provinsi Bali. Pentingnya tarian ini dikaji adalah masih adanya anggapan atau pendapat yang mengatakan tari Renteng di Dusun Saren I, Nusa Penida, Klungkung adalah objek rekonstruksi. Salah satu laporan ilmiah dosen muda yang berjudul Tari Rejang Renteng Sebagai Motivasi Belajar Tari Wali Bagi Wanita di Kota Denpasar, menjelaskan sebagai berikut:

"Tari Rejang Renteng ini merupakan hasil rekuntruksi Dinas Kebudayaan Provinsi Bali pada tahun 1999 oleh Ni Wayan Sulastriani bersama I Nyoman Budi Artha, berlokasi di Pura Dalem Ped dan disosialisasikan kembali serta ditata kembali oleh Ida Ayu Made Diastini. Sebagai hasil rekontruksi Dinas Kebudayaan Provinsi Bali, tari Renteng ini dikembangkan menjadi Rejang Renteng” (Haryati, 2018).

Seminar Tari Rejang Renteng dengan tema viralnya tari Rejang Renteng di Desa Sukasada, Kecamatan Sukasada, Kabupaten Buleleng pada tanggal 21 Oktober 2018 yang lalu dalam rangka Gebyar Seni dan Budaya, Ida Ayu Made Diastini selaku pemakalah sekaligus yang mempopulerkan tarian ini tidak menyebutkan istilah rekonstruksi melainkan menggunakan istilah pengembangan dalam proses penciptaannya. "Pada tahun 1999, tarian ini berhasil dikembangkan oleh Dinas Kebudayaan Provinsi Bali dalam rangka upaya pemerintah untuk melestarikan tarian langka. Rejang Renteng yang sudah merupakan pengembangan dari Dinas Kebudayaan Provinsi Bali pada tahun 1999 yang terinspirasi dari renteng yang ada di Desa Adat Saren, Nusa Gede, Nusa Penida" (Diastini, 2018). Berdasarkan hasil pengamatan, didapatkan kenyataan yang berbeda antara laporan ilmiah dosen muda, dan makalah seminar tari Rejang Renteng. Hasil yang didapatkan dari pengamatan tersebut adalah tari Renteng di Dusun Saren I, Nusa Penida, Klungkung tidak pernah direkonstruksi ataupun dikembangkan menjadi tarian baru. Bentuk tarian ini dikatakan tidak pernah berubah dari awal keberadaannya di Dusun Saren I sampai saat ini baik dari gerak tari, struktur pertunjukannya, ataupun elemenelemen lainnya.

Berdasarkan latar belakang tersebut, terdapat permasalahan yang bersifat krusial dan perlu diluruskan untuk diketahui oleh khalayak umum yaitu (1) Bagaimana bentuk tari Renteng di Dusun Saren I, Nusa Penida, Klungkung? Tujuan penelitian secara umum, menjelaskan secara 
deskriptif interpretatif atas kesenjangan yang terjadi, dengan mengungkapkan fakta dan kenyataan salah satu tari sederhana yang difungsikan sebagai tari ritual di Dusun Saren I, Kecamatan Nusa Penida, Kabupaten Klungkung yaitu tari Renteng. Secara khusus, peneltian ini bertujuan untuk mengetahui dan memahami bentuk, estetika, dan makna tari Renteng di Dusun Saren I, Nusa Penida, Klungkung. Berpijak dari permasalahan yang telah dirumuskan dalam penelitian ini, maka diperlukan landasan teori untuk memahami dan mempelajari subjek yang diteliti dalam rangka membangun konsep landasan berfikir, dengan harapan menghasilkan penelitian yang lebih mendalam. Teori adalah suatu alat yang digunakan untuk menjelaskan permasalahan diteliti, sebagai dasar untuk merumuskan hipotesis. "Teori dalam hal ini dapat digunakan untuk menjelaskan atau memahami hakikat hubungan di antara gejala-gejala yang termasuk dalam ruang lingkup penjelasannya" (Rohidi, 2011).Teori yang diterapkan dalam analisis bentuk tari Renteng di Dusun Saren I, Nusa Penida, Klungkung adalah teori bentuk bermakna dari Clive Bell. "Bentuk bermakna dalam pengertian Bell, merupakan susunan antara komponen formal sebuah karya seni sehingga dapat memicu timbulnya emosi estetis" (Suryajaya, 2016). Susunan antara komponen formal dapat diartikan sebagai unsurunsur atau elemen baku yang tersusun dalam karya seni itu sendiri. Dalam seni tari, komponen tersebut dapat dilihat dari unsur gerak, penari, tata rias dan busana, waktu dan tempat pementasan, struktur, serta unsur penunjang lainnya. Sehingga susunan komponen tersebut menjadi satu kesatuan sebagai objek yang memiliki makna serta dapat menimbulkan pengalaman estetis kepada spektator. Teori bentuk bermakna dari Clive Bell dipilih untuk mengidentifikasi unsur-unsur formal yang dapat memberikan pengalama estetis sebagai ciri khas dari tari Renteng di Dusun Saren I, Nusa Penida, Klungkung.

Hasil penelitian ini dapat bermanfaat dalam memahami secara tekstual bentuk tari Renteng di Dusun Saren I, Nusa Penida, Klungkung, menjadi sumbangsih sebagai kajian yang dapat dipertanggungjawabkan, dan sebagai informasi faktual keberadaan dan bentuk dari tarian ini yang masih eksis dipentaskan sampai saat ini. Semoga melalui penelitian ini tidak ada lagi persepsi bahwa tari Renteng dan tari Rejang Renteng adalah tarian yang sama.

\section{METODE PENELITIAN}

Penelitian tari Renteng di Dusun Saren I, Nusa Penida, Klungkung menggunakan rancangan penelitian kualitatif, yaitu penelitian yang menghasilkan data deskriptif berupa tulisan atau lisan dari objek yang diamati. Bogdan dan Taylor (1975) menjelaskan bahwa "metodologi kualitatif sebagai prosedur penelitian yang menghasilkan data deskriptif berupa kata-kata tulisan atau lisan dari orangorang dan prilaku yang dapat diamati" (Moleong, 2010). Sumber data dalam penelitian ini didapatkan dari data primer dan sekunder. Sember data primer didapatkan dari para informan yang terkait atau mengetahui tari Renteng yaitu Bapak I Ketut Suara selaku mantan kelian adat Dusun Saren I, Jero Mangku Gede Ngurah dan Jero Mangku Ludra selaku pemangku di Pura Merajan Kawitan Keniten Dusun Saren I, serta para penari Renteng yang masih aktif. Sumber data skunder didapatkan dari makalah atau jurnal, salah satunya adalah makalah seminar tari Rejang Renteng yang ditulis dan disajikan oleh Ida Ayu Made Diastini. Penelitian yang dilakukan menggunakan metode pengumpulan data berupa observasi, wawancara, dan dokumentasi.

\section{ANALISIS DAN INTERPRETASI DATA}

Tari Renteng di Desa Saren, Nusa Penida, Klungkung ditarikan secara berkelompok oleh para wanita dewasa dengan menggunakan busana adat ke pura. Tarian ini dipentaskan setelah ritual melis selesai dilakukan atau sebelum prosesi persembahyangan bersama. Sebelum pementasan, para penari melakukan pembersihan diri dengan melukat, dilanjutkan dengan prosesi mendak renteng dengan sarana sesajen atau banten pemendak yang terdiri dari peras pejati dan segehan manca warna. Tarian ini, ditarikan dengan membentuk satu barisan ke belakang atau berderet (berjejer) ke belakang. Perlu diketahui bahwa para penari Renteng tidak saling terhubung atau terikat antara penari satu dengan penari lainnya. Meskipun istilah renteng identik dengan penari yang saling sambungmenyambung, namun bukan itu yang menjadi penekanan utamannya. Renteng atau ngerenteng yang dimaksudkan pada tarian ini adalah rentetan atau rangkaian upacara yang dilakukan di mana tarian ini menjadi bagian dari rentetan tersebut.

Ida Bagus Mahardika memberikan gambaran terkait istilah renteng itu sebagai rentetan atau rangkaian upacara sebagai berikut. "Dalam upacara ada rentetan, runutan upacara yang tidak bisa dipisahkan. Kalau dipisahkan, tidak bisa disebut sebagai rentetan, runutan, untaian, ataupun rangkaian upacara. Renteng yang dimaksudkan dalam tarian ini adalah rentetan atau runutan dari upacara yang dilakukan, tarian inilah penyambungnya" (wawancara, 10 Agustus 2020). Dalam kegiatan upacara keagamaan, terdapat rangkaian-rangkaian ritual yang harus dilakukan. Rangkaian ritual tersebut menjadi satu kesatuan, saling sambung-menyambung antara ritual sebelumnya dengan ritual selanjutnya. Jika ritual yang terdapat pada upacara tersebut dipisah atau tidak menjadi bagian dari upacara maka tidak bisa disebut dengan rangkaian atau rentetan. Tari Renteng di Dusun Saren I, Nusa Penida, Klungkung merupakan penyambung dari rangkaian upacara sebelumnya dengan rangkaian upacara selanjutnya. Dengan demikian, renteng yang dimaksudkan pada tarian ini adalah rentetan, untaian, jalinan, ataupun runutan upacara pioadalan yang disambung oleh tarian sebagai sarananya untuk selanjutnya menuju ke rangkaian upacara berikutnya. 
Tari Renteng di Dusun Saren I, Nusa Penida, Klungkung merupakan tarian yang pementasannya menjadi satu kesatuan dengan pelaksanaan upacara keagamaan (piodalan), baik di Pura Kahyangan Tiga, Pura Dadia ataupun Merajan Kawitan yang ada di Dusun Saren I. Tarian ini juga sebagai sarana persembahan ketika musim jagung meladung, yaitu musim berbuah pada tanaman jagung yang ditandai dengan tumbuhnya rambut (bulu) pada buah jagung. Ritual persembahan jagung meladung dilaksanakan setiap satu tahun sekali. Jero Mangku Ludra mengatakan bahwa "setiap tahun yening wenten penajukan jagung meladung pasti kemargiang antuk sesolahan ring Dalem Ped. Yen ten nyolahang merika ke Dalem Ped, wenten gegodanne" (setiap tahun jika tanaman jagung sudah berbuah akan dilakukan pementasan di Dalem Ped. Jika tidak dipentaskan kesana ke Dalem Ped, akan terjadi wabah) (wawancara, 5 Februari 2020). Sesolahan atau nyolahang yang dimaksudkan oleh narasumber adalah tari Renteng itu sendiri. Berdasarkan pendapat tersebut, tarian ini adalah sarana yang menjadi bagian dalam pelaksanaannya, baik dalam upacara piodalan ataupun ritual persembahan.

Tari Renteng di Dusun Saren I, Nusa Penida, Klungkung ditarikan oleh wanita yang sudah menikah, dan jumlah penarinya harus ganjil yaitu tiga, lima, tujuh, sembilan, sebelas, dan seterusnya. Adapun nama-nama para penari Tari Renteng di Dusun Saren I, Nusa Penida, Klungkung saat ini adalah Ni Made Sedit, Ni Kadek Sulandri, Ni Wayan Luhwati, Ni Wayan Bakti, Ni Wayan Sumudri, Ni Luh Simetri, Ni Wayan Nari, Ni Kadek Dika, dan Ni Nyoman Gani. Para penari renteng bukanlah sekelompok orang yang memiliki ketrampilan khusus dalam menari, karena semua penari renteng tidak melalui proses latihan. Para penari renteng mempelajari tarian ini secara langsung dan autodidak melalui peniruan gerak-gerak tari yang dilakukan oleh penari di posisi depan. Terkait dengan istilah renteng adalah rente (renta) atau tua dalam artian bukan tua fisik melainkan yang dituakan karena status penari adalah seorang pemangku tidaklah benar. Penari renteng secara umum tidak berstatus sebagai pemangku. Pawintenan yang dilakukan hanya pada tingkatan pawintenan dasar atau pawintenan saraswati, yang tujuannya tidak lain untuk dapat mempelajari serta menarikan tarian ini dengan hati yang suci lahir dan bhatin serta untuk melegimitasi penari renteng. "Para penari Renteng terpilih secara niskala" (Diastini, 2018). Pendapat tersebut tidak sepenuhnya benar, berdasarkan penelitian yang dilakukan, terdapat pebedaan pendapat antara tokoh masyarakat setempat dengan penjelasan tari Renteng dalam makalah seminar tari Rejang Renteng. Terpilihnya warga atau masyarakat (wanita yang sudah menikah) menjadi penari Renteng tidak melalui pawisik atau terpilih secara niskala (gaib) melainkan atas dasar keinginannya sendiri. Sedangkan pawisik yang dimaksudkan dalam tarian ini adalah berkaitan dengan jumlah penari yang seharusnya ganjil, atau ketika dipentaskan jumlah penarinya genap.
Tari Renteng di Desa Saren, Nusa Penida, Klungkung memiliki gerak-gerak yang terangkai secara utuh. Meskipun tidak memiliki kompleksitas, namun tetap terdapat variasi unsur yang membangun kesatuan bentuk gerak. Gerak-gerak yang terdapat pada tarian ini dilakukan dengan tempo sedang dan berulang-ulang, serta dilakukan secara kontinu. Gerak tarian ini sangat sederhana, terlihat dari teknik dan cara melakukannya yang tidak begitu sulit. Gerak sederhana pada tarian ini "merupakan gerakan yang tidak rumit, mudah dilakukan serta dapat dipahami... dilakukan dengan teknik yang tidak begitu sulit, namun tepat dan sesuai seperti gerakan penari yang menguasai teknik tari" (Indrawan, 2020). Untuk lebih jelasnya, bentuk gerak tarian ini dapat penulis uraikan sebagai berikut. Ngelikas adalah gerakan berjalan menyilang pada tari Bali. "Gerakan ngelikas dilakukan dengan tempo lambat dengan langkah kaki saling silang disertai dengan ayunan kedua tangan yang diputar di depan badan" (Penyusun, 2000).Gerak ngelikas pada tari Renteng di Dusun Saren I, Nusa penida, Klungkung terdapat di bagian awal dalam struktur pertunjukannya, gerakan ini tidak disertai dengan ayunan tangan yang berputar di depan badan, melainkan ayunan tangan naik dan turun mengikuti langkah kaki. Bentuk gerak ngelikas pada tarian ini dilakukan dengan sikap badan agem kanan, ngembat kiri, badan condong ke kiri, pandangan ke depan. Kaki kanan melangkah di depan kaki kiri, kemudian disusul oleh kaki kanan di belakang kaki kanan sehingga langkah yang ditimbulkan menjadi menyilang. Langkah menyilang tersebut dilihat dari arah hadap badan dan posisi telapak kaki penari. Posisi badan dan telapak kaki para penari Renteng menghadap ke samping kanan, sehingga ketika berjalan ke depan langkah tersebut terlihat menyilang. Kedua tangan penari diayunkan naik dan turun mengikuti langkah kaki.

Nguler adalah "gerakan bergoyang pada badan" (Djayus, 1980). Pada tari Renteng di Dusun Saren I, Nusa Penida, Klungkung gerakan nguler terdapat di bagian tengah pada struktur pertunjukannya. Gerakan ini dilakukan dalam posisi ngembat kiri. Bentuk gerak nguler pada tarian ini dapat dijelaskan sebagai berikut. Sikap badan ngembat kiri dan badan condong ke kiri, gerak tangan ngaweh, dan badan bergoyang agak melingkar disertai dengan kepala ngoleng yang dilakukan secara berulang-ulang. Penekanan gerak nguler pada tarian ini terdapat pada badan penari yaitu ketika gerakan menggoyangkan badan ke kanan dan ke kiri. Sekilas memang terlihat badan penari bergoyang, namun jika diamati secara seksama gerak bergoyang tersebut terjadi karena efek dari bahu penari yang digerakkan memutar ke belakang, sehingga badan penari terlihat bergoyang. Penekanan bentuk pada gerak nguler ini memberikan ciri khas yang dapat menimbulkan identitas bagi tarian ini.

Mentang merupakan desain lurus ke depan atau ke samping pada tangan. "Terdapat dua jenis mentang tangan yaitu mentang kanan dan mentang kiri. Mentang kanan 

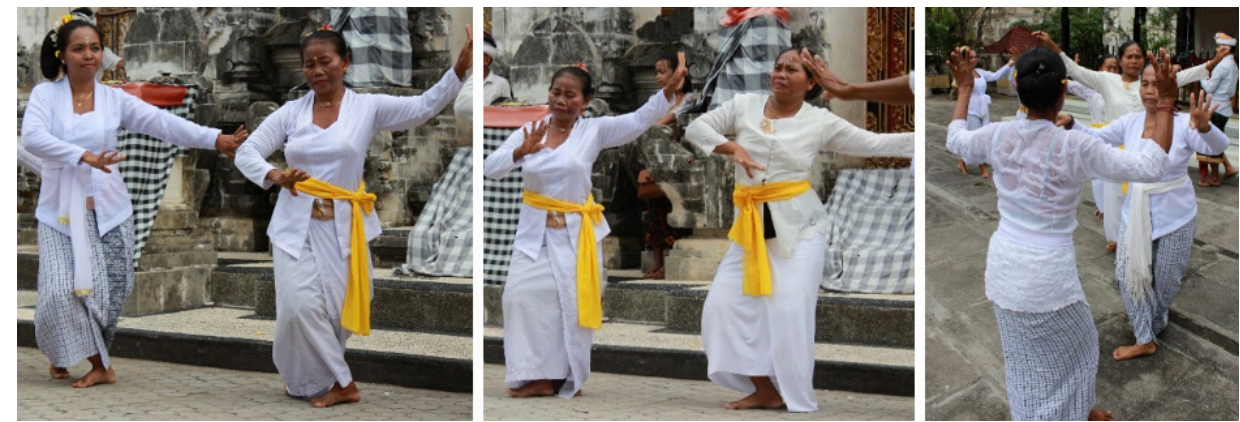

Gambar 1. Gerak ngelikas (kiri), gerak nguler (tengah), dan gerak mentang (kanan) pada tari Renteng.

(Dok. Agung Indrawan, 2020)

adalah tangan kanan dijurulkan ke samping kanan sejajar dengan bahu, sedangkan mentang kiri kebalikan dari mentang kanan yaitu menjulurkan tangan kiri ke samping kiri sejajar dengan bahu" (Fajriani, 2020). Berdasarkan penjelasan di atas, gerak mentang dapat di artikan sebagai sikap atau pose tangan lurus atau dijulurlkan ke samping kanan maupun kiri yang sejajar dengan bahu. Gerak mentang pada tari Renteng di Dusun Saren I, Nusa Penida, Klungkung terdapat di bagian akhir pada struktur pertunjukannya. Gerakan ini dilakukan dalam sikap atau pose kedua tangan menjurul ke samping kanan dan kiri secara bersamaan. Gerak tersebut diawali dengan gerak lokomotor yaitu gerakan berpindah tempat atau titik berat badan dari satu bidang tumpu ke bidang tumpu lainnya. Gerak lokomotor pada tarian ini dilakukan dengan perpindahan posisi badan dan tumpuan kaki melalui putaran badan. Kemudian kedua tangan dijulurkan dengan cara diputar di depan badan dan berakhir lurus ke samping kanan dan kiri, sedangkan posisi kaki kanan jinjit di belakang kaki kiri.

Struktur pertunjukan tari Renteng di Dusun Saren I, Nusa Penida, Klungkung sangat sederhana, tidak seperti pada pertunjukan tari pada umumnya. Tarian ini hanya memiliki tiga gerakan yang dilakukan secara berulangulang dari awal sampai akhir tarian, sehingga struktur tarian ini dibagin menjadi tiga bagian berdasarkan pola gerak yang dilakukan yaitu bagian awal merupakan gerak berjalan (lokomotif) adalah ngelikas, bagian tengah merupakan gerak di tempat (non lokomotif) yaitu nguler, dan bagian akhir merupakan gerak penutup atau transisi menuju ke bagian awal. Keseluruhan bagian tersebut terangkai menjadi satu satu kesatuan struktur tanpa adanya perubahan dinamika ataupun melodi musik iringan tari, serta dilakukan secara repetitif sampai tarian selesai dipentaskan. Sehingga struktur pertunjukan pada tarian ini dapat disebut dengan struktur tunggal. I Wayan Dibia mengatakan bahwa "struktur tunggal merupakan struktur yang terdiri dari bagian-bagian meliputi awal, tengah, dan akhir dalam satu rangkaian (satu kesatuan) yang bulat tanpa adanya pergantian irama musik iringan tari atau perubahan melodi” (Rianta, Santosa, \& Sariada, 2019).

Tempat pentas tari Renteng di Dusun Saren I, Nusa
Penida, Klungkung sifatnya fleksibel, akan tetapi tidak dibuat dengan sengaja melainkan memanfaatkan lahan atau tempat yang ada. Terdapat dua tempat pementasan tarian ini, yaitu tempat pentas dengan memanfaatkan tiga halaman atau tempat sekaligus merupakan tempat pementasan yang dilakukan di tiga lokasi dalam satu areal pura yakni di halaman luar pura, halaman tengah pura, dan halaman utama pura. Seperti di Pura Geria Kawitan Keniten yang berlokasi di Dusun Saren I, yang mana ketiga halaman pura tersebut menjadi satu kesatuan tempat dalam satu kali pementasan. Tempat pentas atau kalangan yang digunakan dalam pementasan tarian ini di pura tersebut dimulai dari halaman luar pura menuju ke halaman tengah dan halaman utama, kemudian dari halaman utama pura kembali lagi ke halaman tengah dan halaman luar pura. Tempat pentas atau kalangan yang terfokuskan di satu tempat, yaitu tempat pementasan yang lokasinya hanya di satu area saja. Kalangan seperti ini tidak bersifat permanen, sama halnya seperti bentuk arena yang dapat dibuat di luar ataupun di dalam ruangan. Pada tari Renteng di Dusun Saren I, Nusa Penida, Klungkung kalangan ini tidak dibuat dengan sengaja, malainkan memanfaatkan halaman pura sebagai tempat pementasannya baik itu di halaman luar pura saja ataupun di halaman utama pura. Salah satu contoh kalangan yang terfokuskan di satu tempat adalah di Pura Penataran Dalem Ped yang memiliki empat area pura yaitu Pura Segara, Pura Taman, Pura Ratu Gede, dan Pura Ratu Mas. Tempat pementasan tarian ini di pura tersebut terfokuskan di halaman luar Pura Ratu Gede dan halaman tengah Pura Ratu Mas. Perbedaan tempat pementasan tari Renteng di Dusun Saren I, Nusa Penida, Klungkung di Pura Kawitan Keniten dengan tempat pementasan di Pura Penataran Dalem Ped (Pura Ratu Gede dan Pura Ratu Mas) adalah tidak menjadi satu kesatuan tempat pentas. Dalam penyajiannya, di pura tersebut (Pura Penataran Dalem Ped) tarian ini dipentaskan sebanyak dua kali di area yang berbeda. Setelah pementasan dan upacara selesai di Pura Ratu Gede, selanjutnya pementasan tarian ini kembali diulang di Pura Ratu Mas.

Tata rias dan busana pada tari Renteng di Dusun Saren I, Nusa Penida, Klungkung sangat sederhana. Rias wajah para penari renteng tidak menonjolkan riasan yang sifatnya kompleks, jenis riasan yang digunakan oleh para penari 
renteng adalah rias natural, yaitu rias wajah yang tidak memberikan dampak perubahan bentuk wajah aslinya, sehingga pengaplikasiannya tergolong mudah dan simpel. Sedangkan busana yang dikenakan oleh para penari antara lain baju kebaya lengan panjang warna putih, selendang warna putih atau kuning, dan kain atau kamen dengan warna dasar putih. Busana yang dikenakan tersebut adalah busana adat untuk upacara keagamaan, yaitu "pakaian yang digunakan pada waktu persembahyangan di pura, sanggah, merajan, dan lain sebagainya" (Agung, 2004). Busana adat, selain digunakan sebagai busana untuk persembahyangan, juga menjadi busana tari yang memberikan identitas pada tarian ini. "Busana adat yang dimaksud adalah busana yang digunakan dalam kegiatan adat sesuai dengan kebiasaan yang berlaku di kalangan masyarakat setempat. Busana adat itulah yang sekaligus menjadi busana tari” (I Wayan Dibia, FX. Widaryanto, 2006).

Musik iringan tari atau gamelan yang mengiringi tari Renteng di Dusun Saren I, Nusa Penida, Klungkung sangat sederhana dan berbentuk konvensional. Instrumen yang digunakan untuk mengiringi tarian ini terdiri dari satu buah kendang, delapan cakep ceng-ceng kopyak, tawa-tawa, satu tungguh trompong, kempur, dan reyong. Menurut I Gede Arya Sugiartha, musik iringan tari dan gending yang dimainkan atau ditabuh untuk mengiringi tarian ini disebut dengan gending rerentengan. Gending tersebut memiliki dua versi yaitu versi trompong, merupakan melodi gending yang dimainkan pada tungguhan trompong, dan versi reyong adalah melodi gending yang dimaikan pada instrumen reyong. Musik iringan tarian ini dapat digolongkan ke dalam jenis musik yang berimbang dan jenis musik yang mendominasi tarian. Jenis musik yang berimbang atau memperlihatkan keberimbangan interaksi antara musik dan tari pada tari Renteng terdapat dalam pementasannya yang menggunakan gending versi trompong. Keberimbangan interaksi yang dimaksudkan pada tarian ini adalah ketika tarian ini dipentaskan di halaman luar dan halaman tengah pura, yang mana musik iringan tarinya akan mengikuti ritme dan tempo gerak tarian. Kemudian, ketika tarian berada di halaman utama pura dan menuju ke halaman tengah musik iringan tari akan mengambil alih ritme dan tempo tarian, sehingga tarian akan mengikuti ritme dan tempo yang dihasilkan oleh musik iringan tari. Jenis musik yang mendominasi tarian terdapat pada versi reyong, karena dilihat dari pertunjukannya, ritme dan tempo tarian ini ditentukan oleh ritme dan tempo yang dihasilkan oleh instrumen reyong. Sehingga tarian ini mengikuti alunan melodi dari reyong untuk menghasilkan ritme-ritme gerakan yang tetap dan ajeg.

Berdasarkan uraian di atas, merujuk pada teori bentuk bermakna dari Clive Bell, terdapat dua hal yang menjadi penekanan dan memberikan ciri khas pada tari Renteng di Dusun Saren I, Nusa Penida, Klungkung. Pertama, dari keseluruhan unsur atau elemen formal yang telah dijelaskan, salah satu unsur atau elemen tarian ini menimbulkan pusat perhatian yaitu unsur gerak yang terdiri dari tiga gerakan pokok yaitu ngelikas, nguler dan mentang. Dari ketiga gerak pokok tersebut, gerak nguler memberikan suatu penekanan yang berbeda dari gerak yang lainnya. Penekanan tersebut, bukan sebagai gerak ngerenteng, melainkan suatu rangkaian gerak atau pola gerak yang menimbulkan pusat perhatian sehingga mengarahkan penonton untuk seolah-olah ikut dalam gerakan tersebut. Gerak nguler pada tarian ini, seperti di jelaskan di atas, dilakukan dengan menggoyangkan badan membentuk desain melingkar. Pusat gerakannya terletak pada bahu yang diputar ke belakang, sedangkan goyangan badan diakibatkan oleh putaran bahu tersebut. Kedua, yang dimaksudkan dengan ngerenteng pada tarian ini bukan dari ikatan atau jalinan yang disimbolkan dengan benda seperti tali maupun selendang. Renteng atau ngerenteng tidak diartikan sebagai tua, dalam artian kondisi fisik dari penari. Arti renteng atau ngerenteng pada tarian ini lebih kepada rangkaian upacara yang dilakukan, dimana tarian ini terdapat didalam rangkaian tersebut sebagai penyambung ritual sebelumnya dengan ritual selanjutnya. Dengan kata lain renteng atau ngerenteng diartikan sebagai rentetan, runtutan, ataupun rangkaian.

\section{SIMPULAN}

Tari Renteng di Dusun Saren I, Nusa Penida, Klungkung tidak pernah direkonstruksi ataupun dikembangkan menjadi tari Rejang Renteng, bahkan unsur atau elemen gerak yang dimiliki tidak ada kaitannya dengan tarian tersebut. Rekonstruksi ataupun pengembangan hanyalah spekulasi ambigu yang dibuat untuk meyakinkan sehingga dapat diterima dengan rasional. Tari Renteng di Dusun Saren I, Nusa Penida, Klungkung dijaga keberadaannya oleh masyarakat setempat sebagai warisan tak benda yang disakralkan. Ngerenteng atau renteng sebagai nama tarian ini tidak mengacu pada usia penari atau status penari sebagai pemangku, juga tidak disimbolkan dengan para penari saling diikat atau memegang tangan maupun selendang. Ngerenteng atau renteng yang dimaksudkan dalam tarian ini adalah rentetan, untaian, jalinan atau runtutan ritual upacara yang dilakukan, di mana tari Renteng sebagai penyambung antara ritual sebelumnya dengan ritual selanjutnya.

Tari Renteng di Dusun Saren I, Nusa Penida, Klungkung memiliki bentuk yang sedarhana. Kesederhanaan tarian ini terlihat dari gerak yang hanya terdiri dari tiga jenis yaitu ngelikas, nguler, dan mentang. Struktur pertunjukannya pun sangat sederhana, yang terdiri dari tiga bagian dan menjadi satu kesatuan sehingga dapat disebut sebagai struktur tunggal. Terdapat dua jenis tempat pentas arena yang digunakan, yaitu pentas arena dengan tiga halaman pura sekaligus dan tempat pentas arena yang terfokuskan di satu halaman pura. Para penari Renteng merupakan 
wanita dewasa (sudah menikah) yang berasal dari Dusun Saren I sendiri. Pemilihan penari renteng tidak melalui pawisik (bisikan gaib), melainkan atas keinginannya sendiri untuk melengkapi jumlah ganjil pada personil penari. Terdapat banten atau sesajen yang harus ada di setiap pementasannya yaitu banten pemendak yang terdiri dari peras pejati dan segehan manca warna. Tata rias yang digunakan oleh para penari renteng adalah rias natural, sedangkan busananya menggunakan pakaian adat persembahyangan yang sekaligus menjadi busana tari. Tarian ini diiringi oleh tungguhan trompong, kendang, tawa-tawa, ceng-ceng kopyak, kempur dan reyong yang disebut dengan rerentengan.

Dari keseluruhan unsur atau elemen-elemen yang terdapat pada tarian ini salah satunya memberikan keunikan dan ciri khas. Unsur tersebut adalah gerak tarinya, namun dari ketiga gerak yang dimiliki, gerak nguler menimbulkan pusat perhatian sehingga memberikan ciri khas. Gerakan ini secara visual (langsung) terlihat sangat kaku, namun jika diperhatikan, desain atau garis yang ditimbulkan oleh badan penari sebagai gerakan ngayab, sehingga gerak nguler pada tarian ini merupakan gerak reperesentatif yang memiliki makna.

\section{DAFTAR RUJUKAN}

Agung, A. A. A. K. (2004). Busana Adat Bali (Edisi dipe). Denpasar: Pustaka Bali Post.

Diastini, I. A. M. (2018). Viralnya Tari Rejang Renteng. Seminar Tari Rejang Renteng, 2. Singaraja: Gebyar Seni Budaya Sukadasa.

Djayus, N. (1980). Teori Tari Bali. Denpasar: Sumber Mas Bali.

Fajriani, N. A. I. Y. (2020). Komposisi Gerak Pada Pertunjukan Kesenian Tari Petuk DI Desa Sade Kabupaten Lombok Tengah. Kaganga: Jurnal Pendidikan Sejarah Dan Riset Sosial Humaniora, 2(2), 97-104. Retrieved from http://journal.ipmk2kpe.or.id

Hadi, Y. S. (2006). Seni Dalam Ritual Agama. Yogyakarta: Penerbit Buku Pustaka.

Haryati, N. M. (2018). Tari Rejang Renteng Sebagai Motivasi Belajar Tari Wali Bagi Wanita Di Kota Denpasar. Denpasar.

Heriyawati, Y. (2016). Seni Pertunjukan dan Ritual. Yogyakarta: Ombak.

I Wayan Dibia, FX. Widaryanto, E. S. (2006). Tari Komunal (Edisi Uji). Jakarta: Lembaga Pendidikan Seni Nusantara.
Indrawan, A. A. G. A. (2020). Konsep Kesederhanaan Tari Renteng Di Desa Saren Nusa Penida, Klungkung, Bali. Gelar: Jurnal Seni Budaya, 18(1), 7-15.

Langer, S. K. (2006). Problematika Seni. Bandung: Sunan Ambu Perss.

Maharsi. (2009). Kamus Jawa Kawi Indonesia. Yogyakarta: Pura Pustaka.

Moleong, L. J. (2010). Metodologi Penelitian Kualitatif. Bandung: PT. Remaja Rosdakarya.

Penyusun, T. (2000). Pendokumentasian Gerak-Gerak Tari Bali. Denpasar: Kantor Dokumentasi Budaya Bali Provinsi Bali.

Rianta, I. M., Santosa, H., \& Sariada, I. K. (2019). Estetika Gerak Tari Rejang Sakral Lanang Di Desa Mayong, Seririt, Buleleng, Bali. Mudra Jurnal Seni Budaya, 34(3), 285-393. https://doi.org/10.31091/mudra.v34i3.678

Rohidi, T. R. (2011). Metodologi Penelitian Seni (Cetakan ke). Semarang: CV. Cipta Prima Nusantara.

Soedarsono, R. M. (1999). Metodologi Penelitian Seni Pertunjukan dan Seni Rupa. Bandung: Masyarakat Seni Pertunjukan Indonesia.

Suharti, M. (2013). Tari Ritual dan Kekuatan Adikodrati. Panggung, 23(4). https://doi.org/10.26742/panggung. v23i4.154

Sumaryono. (2017). Antropologi Tari Dalam Perspektif Indonesia. Yogyakarta: Media Kreativa.

Suryajaya, M. (2016). Sejarah Estetika. Jakarta: Gang Kabel dan Indie Book.

Suryawati, M. (2018). Estetika Tari Sekapur Sirih Sebagai Tari Penyambutan Tamu Di Kota Jambi. Titian: Jurnal Ilmu Humaniora, 02(02), 365-377.

Tasman, A. (2008). Analisis Gerak dan Karakter. Surakarta: ISI Press Surakarta.

Yudabakti, I Made; Watra, I. W. (2007). Filsafat Seni Sakral Dalam Kebudayaan Bali (Cetakan pe). Surabaya: Paramita.

Zoetmulder, P. J. S. O. R. (2004). Kamus Jawa Kuna Indonesia. Jakarta: PT. Gramedia Pustaka Utama.

Daftar Narasumber/Informan

Ida Bagus Mahardika (60th,). Sastrawan, wawancara pada tanggal 10 Agustus 2020 di rumahnya, Jl. Gunung Batur No 29, Br. Sengguan, Kelurahan Semarapura Kangin, 
Klungkung, Bali.

Jero Mangku Ludra (55th,). Pemangku, petani, wawancara pada tanggal 5 Februari 2020 di rumahnya, Dusun Saren I, Desa Pekraman Mujening Temeling, Desa Dinas Batumadeg, Kecamatan Nusa Penida, Klungkung, Bali.

I Gede Arya Sugiartha (54th,). Dosen, wawancara pada tanggal 27 Juli 2020 di Kampus Institut Seni Indonesia Denpasar, Jl. Nusa Indah, Desa Sumerta, Denpasar Timur, Kota Denpasar.

Jero Mangku Gede Ngurah (48th,). Pemangku, petani, wawancara pada tanggal 5 Februari 2020 di rumahnya, Dusun Saren I, Desa Pekraman Mujening Temeling, Desa Dinas Batumadeg, Kecamatan Nusa Penida, Klungkung, Bali. 